УДК 667.6

\title{
ВИВЧЕННЯ ВПЛИВУ МІНЕРАЛЬНИХ НАПОВНЮВАЧІВ НА ВОГНЕЗАХИСНІ ХАРАКТЕРИСТИКИ ВОДНО-ДИСПЕРСІЙНИХ ЛАКОФАРБОВИХ ПОКРИТТІВ
}

Асп. Д. В. Демідов

\section{ИЗУЧЕНИЕ ВЛИЯНИЯ МИНЕРАЛЬНЫХ НАПОЛНИТЕЛЕЙ НА ОГНЕЗАЩИТНЫЕ ХАРАКТЕРИСТИКИ ВОДНО-ДИСПЕРСИОННЫХ ЛАКОКРАСОЧНЫХ ПОКРЫТИЙ}

\author{
Асп. Д. В. Демидов \\ STUDYING THE EFFECT OF MINERAL FILLERS ON THE FIRE-RELEASE \\ CHARACTERISTICS OF WATER-DISPERSION PAINT-AND-PAINT COATINGS
}

Postgraduate student D. Demidov

\begin{abstract}
Розглянуто можливість підвищення вогнезахисної ефективності водно-дисперсійних акрил-стирольних лакофарбових покриттів за допомогою мінеральних дисперсних наповнювачів. У якості наповнювачів застосовували поліфосфат амонію $i$ порожнисті зольні алюмосилікатні мікросфери. Під час проведених досліджень за первинною оцінкою вогнезахисної ефективності розроблених покриттів показано, щуо введення алюмосилікатних мікросфер дозволяе підвищити мічність пінококсового шару при збереженні достатнього коефіцієнта спучування і перевести розроблені матеріали з групи горючих у групу важкогорючих полімерних матеріалів.
\end{abstract}

Ключові слова: водно-дисперсійні лакофарбові покриття, вогнезахисна ефективність, кисневий індекс, антипірен.

Рассмотрена возможность повышения огнезащитной эффективности воднодисперсионных акрил-стирольных лакокрасочных покрытий при помощи минеральных дисперсных наполнителей. В качестве наполнителей применяли полифосфат аммония $u$ полье зольныле алюмосиликатные микросферы. $B$ ходе проведенных исследований по первичной оценке огнезащитной эффективности разработанных покрытий показано, что введение алюмосиликатных микросфер позволяет повысить прочность пенококсового слоя при сохранении достаточного коэффициента вспучивания и перевести разработанные материаль из группы горючих в группу трудногорючих полимерных материалов.

Ключевые слова: водно-дисперсионные лакокрасочные покрытия, огнезащитная эффективность, кислородный индекс, антипирен.

Development paint and varnish compositions to protect metal and non-metallic surfaces is one of the priorities of fire safety in the operation and repair of rolling stock, since the cost of measures aimed at eliminating the effects of fires is many times higher than the cost of their prevention.

The possibility of increasing the fire retardant effectiveness of water-dispersion acrylicstyrene paint and varnish coatings with the help of dispersed mineral fillers is considered. Ammonium polyphosphate and hollow ash aluminosilicate microspheres were used as fillers. The 
assessment of the flame retardant properties of the resulting coatings was evaluated by the "fire tube» method, the characteristics of the coke expanded layer and the oxygen index.

Organic-based protective coatings provide anti-corrosion functions, but in most cases have negligible flame retardant effectiveness. However, such coatings provide more opportunities, so by increasing their thickness, you can increase the fire protection of products, contribute to the localization of fire development, a significant slowdown in the rate of flame propagation and allows you to connect active extinguishing agents. The flame retardant efficiency of the compositions, which swell up depends largely not only on the volume and density of the coke expansion layer, which is formed during combustion, but also on its resistance to burnout and mechanical destruction, adhesion to the protected surface after expansion.

In the course of the studies on the primary assessment of the flame retardant efficiency of the developed coatings, it was shown that the introduction of aluminosilicate microspheres makes it possible to increase the strength of the foam coke layer while maintaining a sufficient expansion coefficient and transfer the developed materials from the group of combustible to the group of combustible polymeric materials.

Keywords: water dispersion paint coatings, flame retardant efficiency, oxygen index, flame retardant.

Вступ. Водно-дисперсійні лакофарбові покриття широко використовуються для отримання захисно-декоративних покриттів на неметалевих поверхнях, проте останнім часом вони все більше використовуються як у побуті, так і в інших галузях промисловості, на транспорті і в будівництві для захисту металу і бетону від дії корозії та підвищених температур [1-3].

Розроблення вогнезахисних покриттів для захисту металевих i неметалевих поверхонь $€$ одним із пріоритетних напрямків пожежної безпеки при експлуатації та ремонті рухомого складу, оскільки вартість заходів, спрямованих на усунення наслідків пожеж, у багато разів перевищує витрати на їхню профілактику. У якості вогнезахисних покриттів використовують вогнезахисні просочення, фарби, лаки, обмазки, штукатурки i плівкові покриття. Різні способи вогнезахисту мають свої переваги i недоліки. Відповідно до відмінності в їхніх експлуатаційних властивостях вони мають різні сфери застосування.

Аналіз останніх досліджень i публікацій. Склади на неорганічних зв'язуючих самі по собі належать до негорючих матеріалів i в загальному випадку $\epsilon$ ефективними вогнезахисними складами, які застосовуються в транспортній промисловості. Однак вони в більшості випадків не забезпечують антикорозійну функцію в процесі експлуатації через низьку механічну міцність при вібрації та ударних навантаженнях. Також недоліком неорганічних покриттів $\epsilon$ їхні великі витрати порівняно 3 органічними покриттями при досягненні однакового рівня вогнезахисної ефективності $[4,5]$.

Захисні покриття на органічній основі, навпаки, забезпечують антикорозійні функції, але в більшості випадків мають незначну вогнезахисну ефективність. Вогнезахисні покриття на органічних зв'язуючих забезпечують більш широкі можливості. Так, за рахунок збільшення їхньої товщини можна підвищити вогнестійкість виробів, що сприяє локалізації розвитку пожежі, значному уповільненню швидкості поширення полум'я i дозволяе підключити активні засоби гасіння [6-8].

Тому при вирішенні проблеми підвищення вогнезахисних властивостей покриттів на органічній основі, а саме екологічно доцільних водно-дисперсійних покриттів, одночасно необхідно вирішити такі проблеми: захист виробів у транспортній промисловості від дії підвищених 
температур, агресивних чинників середовища у процесі експлуатації, а також підвищення ефективності самого вогнезахисного складу.

\section{Визначення мети та задачі} дослідження. Підвищення ефективності вогнезахисного складу на основі акрилстирольної водної дисперсії шляхом раціонального поєднання діючих компонентів: органічного зв'язуючого i мінеральних наповнювачів, таких як поліфосфат амонію і порожнистих зольних алюмосилікатних мікросфер.

\section{Основна частина дослідження.} Основні принципи побудови рецептур вогнезахисних покриттів на основі органічних водних дисперсій аналогічні рецептурами традиційних лакофарбових матеріалів: плівкоутворювач, наповнювачі, пігменти (якщо необхідно), реологічні добавки, сикативи (якщо необхідно), технологічні добавки. Головна відмінність - наявність антипірену, що відповідає за процес утворення пінококсу, який виступає в ролі фізичного бар'єру, знижуючи теплоi масоперенесення від газової до конденсованої фази.

Використовуються такі види антипіренів: галоген-, фосфор-, бор- і азотовмісні сполуки; оксиди, солі і комплексні сполуки різних металів; органічні сполуки, до складу яких входить кілька гетероатомів. Антипірени можуть вводитися в полімерне органічне зв'язуюче як у вигляді індивідуальних речовин, так i по кілька сполук одночасно.

На сьогодні більше $15 \%$ всіх антипіренів, які підвищують ефективність вогнезахисних складів, складають солі i ефіри фосфорних кислот. Дію фосфору та його сполук $\mathrm{y}$ якості антипіренів пов'язують 3 таким чинником, як специфічний вплив фосфорних сполук на процеси, що протікають у конденсованій фазі при горінні полімерів. Фосфорні антипірени або продукти їхнього перетворення служать агентами та свого роду каталізаторами реакцій відщеплення заступників у макромолекулярному ланцюзі, циклізації та інших реакцій полімерів. Хімічні перетворення полімерів при цьому спрямовано на збільшення виходу нелеткого коксового залишку та зменшення горючих продуктів піролізу; утворення поверхневого склоподібного або в'язкого розплавленого шару поліметафосфорної кислоти. Цей шар служить фізичним бар'єром для перенесення тепла від полум'я до полімеру і дифузії горючих продуктів у зону горіння, а також впливає на гетерогенне окиснення карбонізованих продуктів піролізу полімерів $[9,10]$.

У даній роботі представлено результати первинного оцінювання вогнезахисних властивостей розроблених лакофарбових покриттів на основі водно-дисперсійного акрил-стирольного сополімеру, наповненого поліфосфатом амонію (ПФА) і порожнистими зольними алюмосилікатними мікросферами (МС) [11-13]. Основною характеристикою ПФА для вогнезахисного складу є вміст азоту і фосфору, які повинні знаходиться в межах 14-15\% азоту і не менше $70 \%$ фосфору відповідно. Порожнисті зольні алюмосилікатні мікросфери являють собою дрібнодисперсні порошки, які складаються 3 тонкостінних $(0,25-$ 10 мкм) алюмосилікатних, натрійкалійборосилікатних частинок сферичної форми діаметром 10-500 мкм i насипною щільністю до 0,2 г $/ \mathrm{cm}^{3}$.

Вогнезахисні властивості отриманих покриттів оцінювали методом «вогнева труба», характеристиками коксового спученого шару (коефіцієнт спучення та механічна міцність) і кисневим індексом.

Метод «вогнева труба» широко використовується в дослідницьких цілях. Сутність методу полягає у визначенні втрати маси зразками деревини, обробленими випробовуваними покриттями при вогневому випробуванні в умовах, сприятливих акумуляції тепла, і дозволяє визначити групу вогнезахисної ефективності: для I групи втрати маси після спалювання повинні складати не більше 
$9 \%$, для II - від 9 до $25 \%$, якщо втрати маси зразка більше $25 \%$, то покриття вважається горючим. Для випробовувань за методом «вогнева труба» були підготовлені зразки соснової деревини розміром $150 \times 60 \times 30$ мм, які були оброблені досліджуваними покриттями товщиною 1 мм залежно від вмісту мінеральних наповнювачів.

Вогнезахисна ефективність складів, що спучуються, багато в чому залежить не тільки від об'єму та щільності коксового спученого шару, який утворюється при горінні, а й від його стійкості до вигоряння i механічного руйнування, адгезії до поверхні, що захищається після спучування. Тому було визначено коефіцієнт спучення. На металеві пластини розміром $100 \times 100$ мм попередньо наносили розроблені склади товщиною не більше 1 мм, поміщали в муфельну піч і витримували протягом 5 хв при температурі $600 \pm 5{ }^{\circ} \mathrm{C}$. Механічну міцність спучених складів

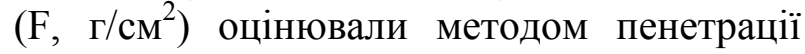
поверхні пінококсу індентором діаметром 5 мм [14-17].

Для порівняльної оцінки горючості розроблених покриттів у певних контро- льованих умовах визначали кисневий індекс (КI) відповідно до ДСТУ EN ISO 4589-2:2015. Такий метод можна застосовувати тільки як один 3 елементів оцінки пожежної небезпеки покриттів.

Результати випробувань коефіцієнта спучування (Кc), механічної міцності (F, $\left.\Gamma / \mathrm{cm}^{2}\right)$, втрати маси після випробовування методом «вогнева труба» $(\Delta \mathrm{m}, \%)$ i кисневий індекс (КI, \%) отриманих покриттів залежно від ступеня наповнення мікросферами (MC) і поліфосфатом амонію (ПФА) наведено на рис. 1.

3 рис. 1 видно, що на вогнезахисні властивості суттєвий вплив має антипірен ПФА. При введенні наповнювача МС в кількості 40 мас. \% спостерігається незначне збільшення КІ до $24 \%$ за рахунок зменшення частки акрил-стирольного зв'язуючого i збільшення частки негорючого мінерального наповнювача, що дозволяє віднести такі матеріали до групи «важкозаймистих» матеріалів, які не підтримують горіння в атмосфері повітря $(\mathrm{KI}>21 \%)$, за рахунок зменшення концентрації горючих газів у зоні горіння.

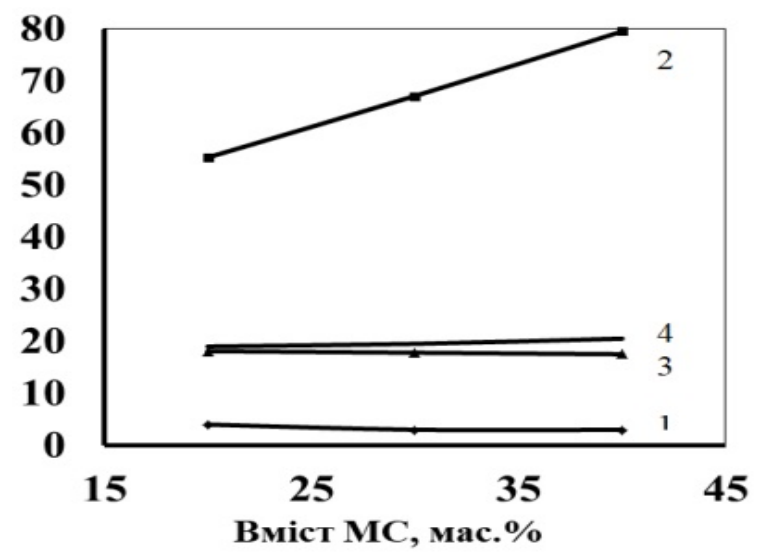

a)

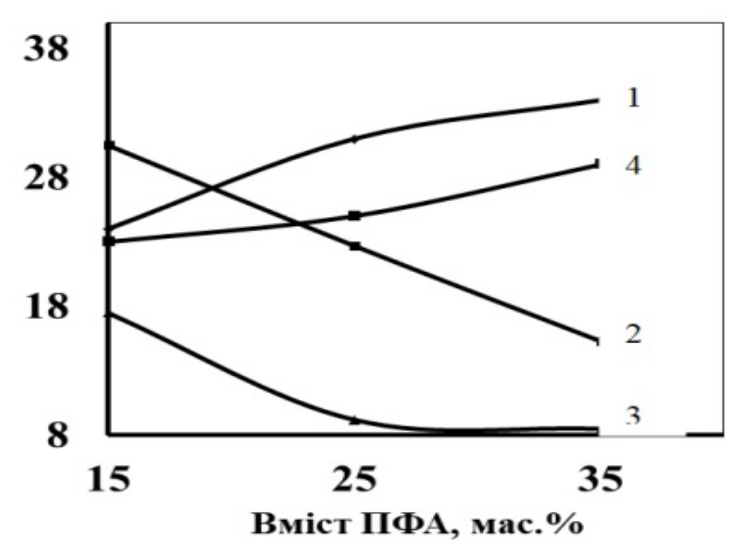

б)

Рис. 1. Оцінка вогнезахисних властивостей залежно від ступеня наповнення МС (a) та ПФА (б): 1 - Кс, 2 - F, 3 - втрати маси, 4 - КІ

При введенні антипірену ПФА КІ підвищується до $30 \%$, що дозволяє пере- вести розроблені матеріали з групи горючих у групу важкогорючих і самозагасаль- 
них (KI > 27 \%) полімерних матеріалів, що $є$ основним критерієм їхньої негорючості.

Далі на рис. 2 представлені графічні залежності отриманих покриттів залежно від спільного впливу мікросфер (МC) i поліфосфату амонію (ПФА), коефіцієнта спучування (Кс), механічної міцності (F, $\left.\Gamma / \mathrm{cm}^{2}\right)$, втрат маси після випробовування методом «вогнева труба» $(\Delta \mathrm{m}, \%)$ i величини кисневого індексу (КІ, \%).

Як видно 3 наведених даних рис. 2,a введення мікросфер призводить до зниження коефіцієнта спучування: за рахунок збільшення питомої щільності утворюється пінококс, у структуру якого впроваджуються негорючі алюмосилікатні мікросфери, причому при збільшенні вмісту мікросфер зниження коефіцієнта спучування відбувається непропорційно, що, на перший погляд, пов'язано з певною граничною кількістю впроваджуваних у структуру пінококсу мікросфер, як наслідок, надлишок мікросфер не бере участі в утворенні пінококсового шару.

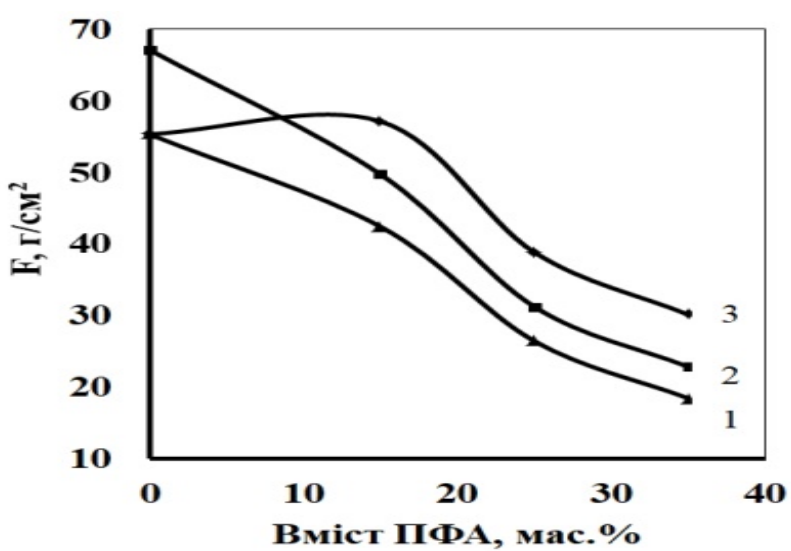

6

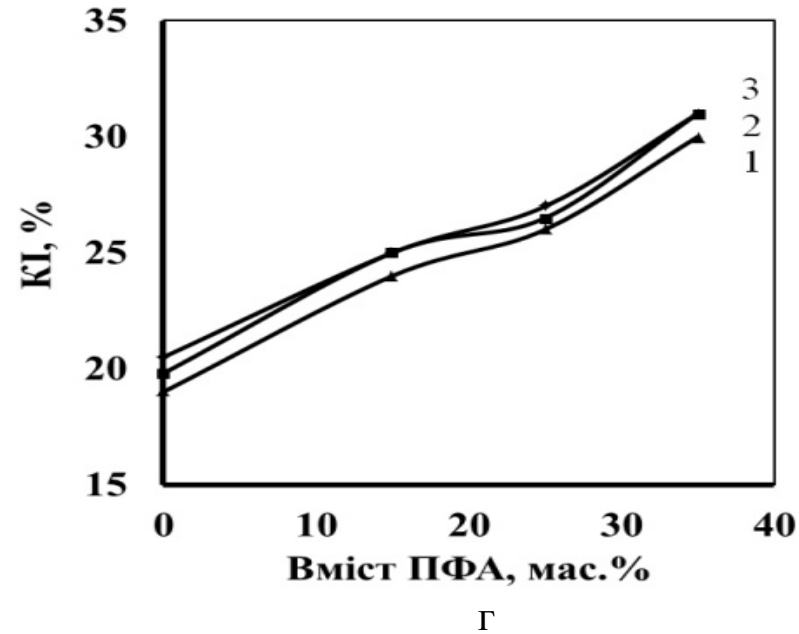

Рис. 2. Оцінка вогнезахисних властивостей залежно від ступеня наповнення МС: $1-20$ мас. $\%, 2-30$ мас. $\%, 3-40$ мас. $\%$

На рис. 2,б показано, що введення мікросфер дозволило підвищити міцність пінококсу (до Кс $=57$ разів) за рахунок впровадження в його структуру досить міцних агрегатів алюмосилікатних мікросфер.

Дослідження втрат маси наведено на рис. 2,в. Як видно з отриманих залежностей 
зі збільшенням частки ПФА і МС втрати маси знижуються (до $\Delta \mathrm{m}=7,3 \%$ ), що досягається при максимальному вмісті ПФА і МС, що обумовлено збільшенням частки негорючих мінеральних наповнювачів.

Зміну кисневого індексу від вмісту ПФА наведено на рис. 2,г. 3 наведених залежностей видно, що при спільному використанні антипірену (ПФА) і алюмосилікатних мікросфер відбувається збільшення КІ на 2-3\% за рахунок зменшення частки продуктів горіння акрилстирольного зв'язуючого і збільшення частки негорючого мінерального наповнювача, а так само за рахунок зниження міграції горючих газів у зону горіння в результаті зменшення пористості пінококсового шару

Висновки. У результаті проведених досліджень вогнезахисних властивостей отриманих покриттів від вмісту і типу наповнювачів показано, що введення поліфосфату амонію дозволяє перевести акрил-стирольні покриття в групу важкогорючих матеріалів (КІ до 24-29 \%), які характеризуються високим коефіцієнтом спучування (Кс до 35 разів), але недостатньою міцністю пінококсу (до $\left.\mathrm{F}=15-30 \Gamma / \mathrm{cm}^{2}\right)$, що в умовах реальної пожежі не дозволяє утворювати міцний пінококсовий шар i, як наслідок, погіршує вогнезахисні властивості утвореного пінококсового шару.

Під час досліджень вогнезахисних характеристик водно-дисперсійних лакофарбових покриттів за рахунок мінеральних наповнювачів з'ясовано, що введення алюмосилікатних мікросфер дозволяє в 1,5-2 рази підвищити міцність пінококсового шару (до $\mathrm{F}=30,5-57,1 \quad$ г/ $\mathrm{cm}^{2}$ ) при збереженні достатнього коефіцієнта спучування (до Кс $=18$ разів) за рахунок впровадження мікросфер у структуру пінококсового шару при збільшенні кисневого індексу $(\mathrm{KI}=25-31 \%)$ і перевести розроблені матеріали 3 групи горючих у групу важкогорючих полімерних матеріалів.

\section{Список використаних джерел}

1. Лобковский, В. Водно-дисперсионные краски для защиты металла и бетона от коррозии [Текст] / В. Лобковский // Промышленная окраска. - 2016. - № 4. - С. 28-31.

2. Казакова, Е.Е. Водно-дисперсионные акриловые лакокрасочные материалы строительного назначения [Текст] / Е. Е. Казакова, О. Н. Скороходова. - М. : ООО «ПэйнтМедиа», 2003. - $136 \mathrm{c.}$

3. The transition to the replacement of organic solvents by aqueous solvents is supported by the government and association of all countries [Text] // Chemistry of Ukraine. - 2012. - Vol. 70. $53 \mathrm{p}$.

4. Балакин, В. М. Первичная оценка огнезащитных свойств вспучивающихся покрытий на основе различных водных дисперсий [Текст] / В. М. Балакин, А. М. Селезнёв, К. В. Белоногов // Пожаровзрывобезопасность. - 2010. - Т. 19. - № 6. - С. 14-18.

5. Беликов, А. С. Применение жидкостекольных композиций в качестве огнезащитных покрытий [Текст] / А. С. Беликов // Вопросы химии и химической технологии. - 2000. - №1. - С. 104-107.

6. Дослідження вогнезахисної ефективності епоксиполімерного покриття «ANTIFIRE» [Текст] / Ю. М. Данченко, Т. М. Обіженко, В. А. Андронов, Н. В. Саєнко // Науковий вісник будівництва. - 2017. -Т. 89. - № 3. - С. 215-223.

7. Саенко, Н. В. Первичная оценка огнезащитных свойств водно-дисперсионных акриловых покрытий теплоизоляционного назначения [Текст] / Н. В. Саєнко, Д. В. Демидов // Науковий вісник будівництва. - 2016. - Т. 86. - № 4. - С. 154-57. 
8. Оценка эффективности применения эпоксидных полимерных композиций для огнезащиты клееной древесины [Текст] / В. А. Андронов, Ю. М. Данченко, Н. В. Саенко [и др.] // Проблемы пожарной безопасности. - 2014. - Вып. 36. - С. 10-16.

9. Влияние антипиренов на показатели пожарной опасности эпоксиполимерных материалов [Текст] / Р. А. Яковлева, Е. Ю. Спирина-Смилка, Ю. В. Попов [и др.] // Проблемы пожарной безопасности: сб. науч. трудов. - 2011. - Вып. 29. - С. 175-181.

10. Визначення міцносних характеристик теплоізолюючого спученого шару вогневібростійких покриттів для протипожежного захисту металевих виробів [Текст] / А. I. Березовський, I. Г. Маладика, Н. В. Саєнко, Ю. В. Попов // IV міжнар. наук.-практ. конф. «Теорія і практика гасіння пожеж та ліквідації надзвичайних ситуацій». - Черкаси, 2012. - C. 172-177.

11. Rheological properties of aquaeous dispersion of styrene acrylate copolymer incorporating hollow microspheres and AEROSIL [Electronic source] / N. Saienko, D. Demidov, Y. Popov, R. Bikov, V. Butskyi // MATEC Web of Conferences. - 2018. - Vol. 230. - 8 p. https://doi.org/10.1051/matecconf/201823003017.

12. Вахитова, Л. Н. Жидкокерамические теплоизоляционные покрытия - новое слово в энергосбережении [Текст] / Л. Н. Вахитова, А. А. Завертатный // F+S: технологи безопасности и противопожарной защиты. - 2010. - № 3 (45). - С. 64-66.

13. Panchenko, I. Thermal insulation coating based on water-based polymer dispersion [Electronic source] / I. Panchenko, M. Akulova, D. Panchenko // MATEC Web of Conferences. 2018. - Vol. 143. - 7 p. - http://doi.org/10.1051/matecconf/201814302007.

14. Березовский, А. И. Определение коэффициента вспучивания и прочностных характеристик вспученного слоя огнезащитных вибростойких покрытий для противопожарной защиты металлических элементов и конструкций [Текст] / А. И. Березовский, И. Г. Маладыка // Вестник Университета гражданской защиты МЧС Беларуси. - 2013. - № 1. - С. 59-67.

15. Влияние ко-интеркалированных соединений графита на показатели огнезащитных свойств вспучивающихся огнезащитных композиций [Текст] / Р. А. Яковлева, Е. Ю. Спирина, Ю. В. Попов [и др.] // Науковий вісник будівництва. - Харків : ХДТУБА, 2010. - Вип. 59. - С. 259-263.

16. Собурь, С. В. Огнезащита материалов и конструкций [Текст]: справочник / С. В. Собурь. - М. : Спецтехника, 2002. - 240 с.

17. Flame retardancy and toughening properties of epoxy composites containing ammonium polyphosphate microcapsules and expanded graphite [Electronic source] / D. He, C. Zhao, H. Gou, Y. Li, D. Xiang // High Performance Polymers. - 2018. - Vol. 30. - Iss. 10. - P. 1247-1259. http://doi:10.1177/0954008317747952.

Демідов Дмитро Васильович, аспірант кафедри загальної хімії Харківського національного університету будівництва та архітектури. Тел.: (050) 878-61-71. E-mail: natause@ukr.net. ORCID 0000-0002-9530-3500.

Демидов Дмитрий Васильевич, аспирант кафедры общей химии Харьковского национального университета строительства и архитектуры. Тел.: (050) 878-61-71. E-mail: natause@ukr.net. ORCID 0000-0002-9530-3500.

Dmitriy Demidov, postgraduate student department of general chemistry Kharkiv National University of Civil Engineering and Architecture. Tel.: (050) 878-61-71. E-mail: natause@ukr.net. ORCID 0000-0002-9530-3500.

Статтю прийнято 17.12.2018 p. 